\title{
Bat Survey of Writing on Stone Provincial Park \\ - a compilation of work since 1985 -
}

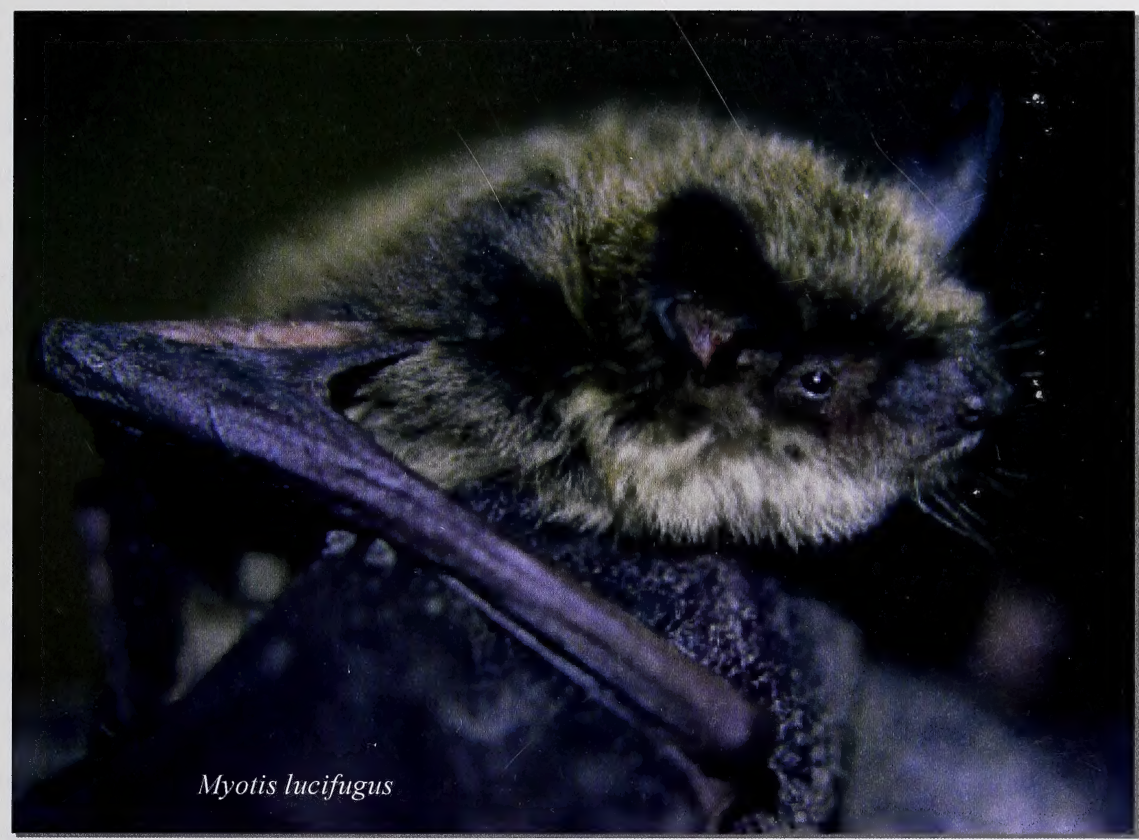

Prepared by: Cori L. Lausen

Department of Biological Sciences

University of Calgary

Calgary, Alberta T2N 1N4

corilausen@hotmail.com

January, 2004

Prepared for: Alberta Natural Heritage Information Centre

Parks and Protected Areas Division

2nd floor, Oxbridge Place

9820 - $106 \mathrm{St}$.

Edmonton, Alberta T5K 2J6 



\section{INTRODUCTION}

Writing on Stone Provincial Park (WOS) is located along an area of the Milk River where rocky outcroppings are abundant. This terrain provides excellent roosting habitat for several species of bats. There are also clumps of cottonwood trees along the river, which provide foraging habitat for all prairie bats.

While bats have been captured in the park for many years, there has been no compilation of records, and there has been confusion over what areas of the park have and have not been surveyed for bats. Because much of the bat work in the park over recent years has been associated with public presentations, a great deal of netting has been done in the campground, amphitheatre and playground areas (Figure 1 public area/campground). In a research proposal to the Alberta Natural Heritage Information Centre, Tim Schowalter expressed concern that other less accessible locations in the park have not been surveyed for bats and should be in order to properly represent bat fauna in the area. He also expressed the concern that less common species may be missed if these less accessible areas are not explored. For example, the Western Big -eared Bat, Corynorhinus townsendii, is particularly sensitive to human disturbance (Nagorsen and Brigham 1993) and in the Montana prairies, lives in simila r habitat to what is found along the Milk River (pers. obs.); only $70 \mathrm{~km}$ south of the Milk River this species is plentiful, raising speculation that it may be found in the Writing on Stone area in some of the deep rocky coulees running through the southern portion of the park.

In addition to the bat work that I have done in the public areas of WOS, I spent four days netting bats in the restricted area of the park south of the Milk River. In this report I describe my capture records and compile netting records for bat work done in the park since 1985.

\section{METHODS}

I captured bats by placing mist-nets off of rock edges such that at least one end of the net was flush with a rock surface. Alternatively nets were strung between trees and bushes, or between hoodoo formations in flyway areas of coulees. Nets ranged in length from $1.8 \mathrm{~m}$ to $18 \mathrm{~m}$ (six to 60 feet), and were strung on poles ranging from $3 \mathrm{~m}$ to $6 \mathrm{~m}$ (10 to 20 feet) high. I netted four areas of WOS Park (Figure 1) on July $27-30,2003$.

All netting locations were on the south side of the Milk River in the Restricted Area of the park. Two were near the river and two were $2.75-4.6 \mathrm{~km}$ south of the river. The former netting sites were in Humphrey Coulee (N 49 04.380', W $111^{\circ} 36.930^{\prime}$ ) and Van Cleeve/Rocky Coulee (N 49 04.430', W $111^{\circ}$ 39.300'). The 'non-river' netting sites were in Davis Coulee (mid-way on the west arm at a rocky area in conjunction with a spring at $\mathrm{N} 49^{\circ} 03.420^{\prime}$, W $111^{\circ} 37.470^{\prime}$ ), and at a small body of water (approximately $30 \mathrm{~m} \times 150 \mathrm{~m}$, and created by a dam across the small creek that runs into Davis Coulee) located on prairie

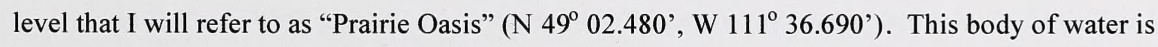
surrounded by a few $(<15)$ small trees. The bottoms of the coulees consist of small shrubs/bushes (Davis and Van Cleeve/Rocky Coulees also contain small active creeks) with few cottonwood trees. Unlike river 
Digitized by the Internet Archive in 2015

https://archive.org/details/batsurveyofwritio0laus 
valley walls in many other parts of the Milk River, these coulees consist of mainly hard sandstone walls, with less of the soft eroded mudstone that is dominant in areas such as the Pinhorn Grazing Reserve and Onefour Substation further downriver. The netting site in Davis Coulee was the narrowest $(<50 \mathrm{~m}$ wide $)$ of the three coulee sites with thick vegetation and steep rock walls.

Figure 1. Map of the Writing on Stone Provincial Park area showing major coulees and the public campground area. Sites where bats were netted in this survey are indicated with a blue cross-checked box.

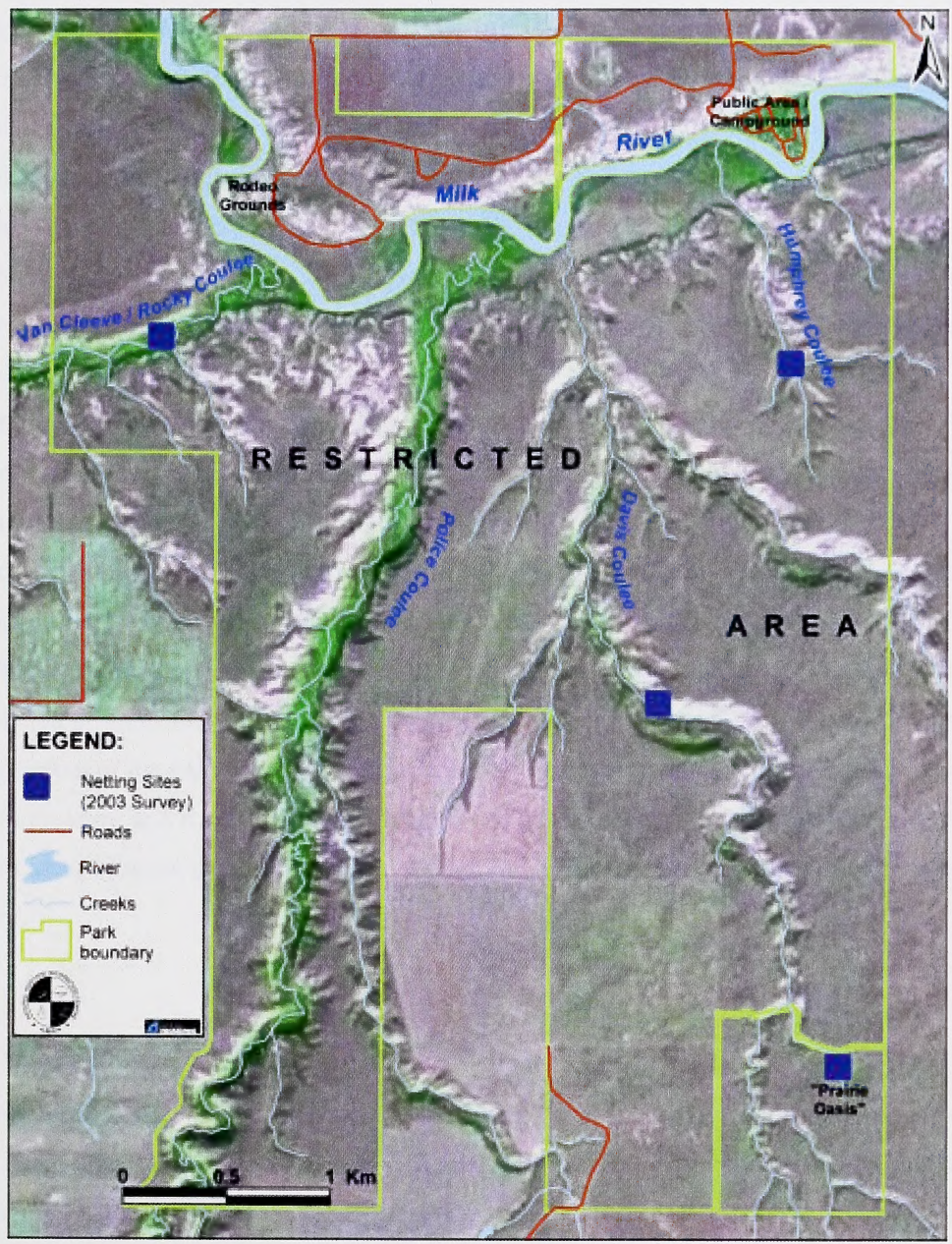

Individuals were identified to species. Adult bats were distinguished from juvenile bats by examining the joints in the fingers; adults have fully ossified epiphyses. I classified females as reproductive if they were pregnant, lactating, or post-lactating. 

The following measurements were made: forearm length, mass, ear length (M. evotis only). Three separate forearm measurements were taken for each bat and averaged. A portable digital scale was used to take mass after the bat had been held for a minimum of one hour. Relative age was obtained by looking at the degree of toothwear (class 1 reserved for juveniles and class 7 representing the most worn category). For further details, consult Holroyd (1993).

Additionally, tissue was sampled for genetic analysis. A $2 \mathrm{~mm}$ diameter disposable biopsy punch was used to take a sample of wing tissue from each plagiopatagium. The biopsy sample is taken by spreading the wing (or tail membrane) of the bat over a soft plastic cutting board until it is taut. The membrane is carefully examined to avoid cutting blood vessels. The excised piece of tissue is placed in $90 \%$ ethanol. Biopsy punches are flamed and dipped into ethanol, and the cutting board is also washed with ethanol, to sterilize equipment between individuals.

While genetic analysis is not part of this survey, biopsy punches of tissue were taken in lieu of banding. Some of these samples have been passed on to researchers investigating phylogenetic relationships between species. Any samples not used will be stored in the "tissue collection" at the Provincial Museum of Alberta.

Although a remote echolocation recording system (Anabat) was used to record calls, because of the large capture numbers together with observations made at dusk and dawn, analysis of these tapes was deemed unnecessary.

I compiled records of bat captures from WOS from 1985 to 2003 . Most of these captures were made by Matt Saunders while working under the supervision of R.M.R. Barclay (University of Calgary). He netted bats in the WOS area May 4 - Aug. 20, 1987 and May 17 - Aug. 12, 1988. Netting sites covered both the park and private lands bordering the park, north and south of the river. Netting of bats in the campground region of the park in association with public presentations was carried out by myself, $\mathrm{L}$. Wilkinson, S. Holroyd and R.M.R. Barclay, but because these captures were not always documented, and/or record of all of these data could not be located, only some of these captures have been included in this summary.

\section{RESULTS}

\section{July 2003 Captures}

I captured 77 individuals and six species (Tables 1 and 2). No Corynorhinus townsendii were captured. The greatest species diversity was in Rocky Coulee, but the largest number of bats was captured at Prairie Oasis. Myotis lucifugus (MYLU) was the most abundant species (48/77, 62\% of captures), and had the greatest skew in adult sex ratio $(46 / 47,98 \%$ adult males; $1 / 47,2 \%$ adult females, non-reproductive only). My survey results indicate species abundance from most to least is as follows: M. lucifugus, M. evotis, M. volans, and M. ciliolabrum. However, this differs from the more extensive netting records of M. Saunders (see below). 

Table 1. Bat captures July 27-30, 2003 made at four locations in the southern part of Writing on Stone Provincial Park. Males (M) and females (F) are counted separately as are juveniles (Juv), and in some cases sex was not recorded (Undet.). Whether reproductive (Repro) individuals were captured is indicated. Forearm measurements (F.A. Avg.) and ear length are presented as mean values of three averaged values per individual, and units are in $\mathrm{mm}$. Mass is given in units of grams and toothclass (TC) is presented as an average relative toothwear value ranging from 1 (juveniles - no wear) to 7 (extensive wear). The following species abbreviations are used: EPFU (Eptesicus fuscus), LACI (Lasiurus cinereus), MYCI (Myotis ciliolabrum), MYEV (Myotis evotis), MYLU (Myotis lucifugus), MYVO (Myotis volans) and LANO (Lasionycteris noctivagans).

\begin{tabular}{|c|c|c|c|c|c|c|c|c|}
\hline Species & Sex & $\begin{array}{l}\text { Number } \\
\text { captured }\end{array}$ & $\begin{array}{l}\text { Repro Bats } \\
\text { Captured? }\end{array}$ & $\begin{array}{l}\text { F.A. Avg. } \\
(\mathrm{mm})\end{array}$ & $\begin{array}{l}\text { Mass } \\
(\mathrm{g})\end{array}$ & $\mathrm{TC}$ & $\begin{array}{c}\text { Ear } \\
\text { Length } \\
(\mathrm{mm})\end{array}$ & $\begin{array}{l}\text { Total number } \\
\text { per species }\end{array}$ \\
\hline \multirow[t]{4}{*}{ EPFU } & $\mathrm{M}$ & 1 & yes & 48.00 & 19.9 & 7.0 & $\mathrm{n} / \mathrm{a}$ & 2 \\
\hline & $\mathrm{F}$ & 1 & yes & 47.90 & 17.5 & 6.0 & $\mathrm{n} / \mathrm{a}$ & \\
\hline & Juv M & 0 & & & & & & \\
\hline & Juv F & 0 & & & & & & \\
\hline \multirow[t]{4}{*}{ LACI } & $\mathrm{F}$ & 0 & & & & & & 2 \\
\hline & Juv M & 1 & $\mathrm{n} / \mathrm{a}$ & 51.15 & 18.2 & 1.0 & $\mathrm{n} / \mathrm{a}$ & \\
\hline & Juv F & 0 & & & & & & \\
\hline & undetermined* & 1 & & & & & & \\
\hline \multirow[t]{4}{*}{ MYCI } & $\mathrm{M}$ & 3 & no & 31.33 & 4.7 & 3.0 & $\mathrm{n} / \mathrm{a}$ & 3 \\
\hline & F & 0 & & & & & & \\
\hline & Juv M & 0 & & & & & & \\
\hline & Juv F & 0 & & & & & & \\
\hline \multirow[t]{4}{*}{ MYEV } & $\mathrm{M}$ & 0 & & & & & & 15 \\
\hline & F & 14 & yes & 38.35 & 7.1 & 4.6 & 18.5 & \\
\hline & Juv M & 1 & $\mathrm{n} / \mathrm{a}$ & 37.02 & 5.8 & 1.0 & 18.0 & \\
\hline & Juv F & 0 & & & & & & \\
\hline \multirow[t]{4}{*}{ MYLU } & $\mathrm{M}$ & 46 & yes & 37.42 & 7.4 & 3.3 & $\mathrm{n} / \mathrm{a}$ & 48 \\
\hline & F & 1 & no & 39.70 & 7.6 & 2.0 & $\mathrm{n} / \mathrm{a}$ & \\
\hline & Juv M & 0 & & & & & & \\
\hline & Juv F & 1 & $\mathrm{n} / \mathrm{a}$ & 36.97 & 7.2 & 1.0 & $\mathrm{n} / \mathrm{a}$ & \\
\hline \multirow[t]{4}{*}{ MYVO } & M & 7 & yes & 38.37 & 7.3 & 3.2 & $\mathrm{n} / \mathrm{a}$ & 8 \\
\hline & $\mathrm{F}$ & 1 & no & 38.65 & 7.2 & 2.0 & $\mathrm{n} / \mathrm{a}$ & \\
\hline & Juv M & 0 & & & & & & \\
\hline & Juv F & 0 & & & & & & \\
\hline \multirow[t]{3}{*}{ LANO } & $\mathrm{F}$ & 0 & & & & & & 0 \\
\hline & Juv M & 0 & & & & & & \\
\hline & Juv F & 0 & & & & & & \\
\hline
\end{tabular}

Total

*observed but not captured 

Table 2. Bat captures July 27-30, 2003 according to netting location.

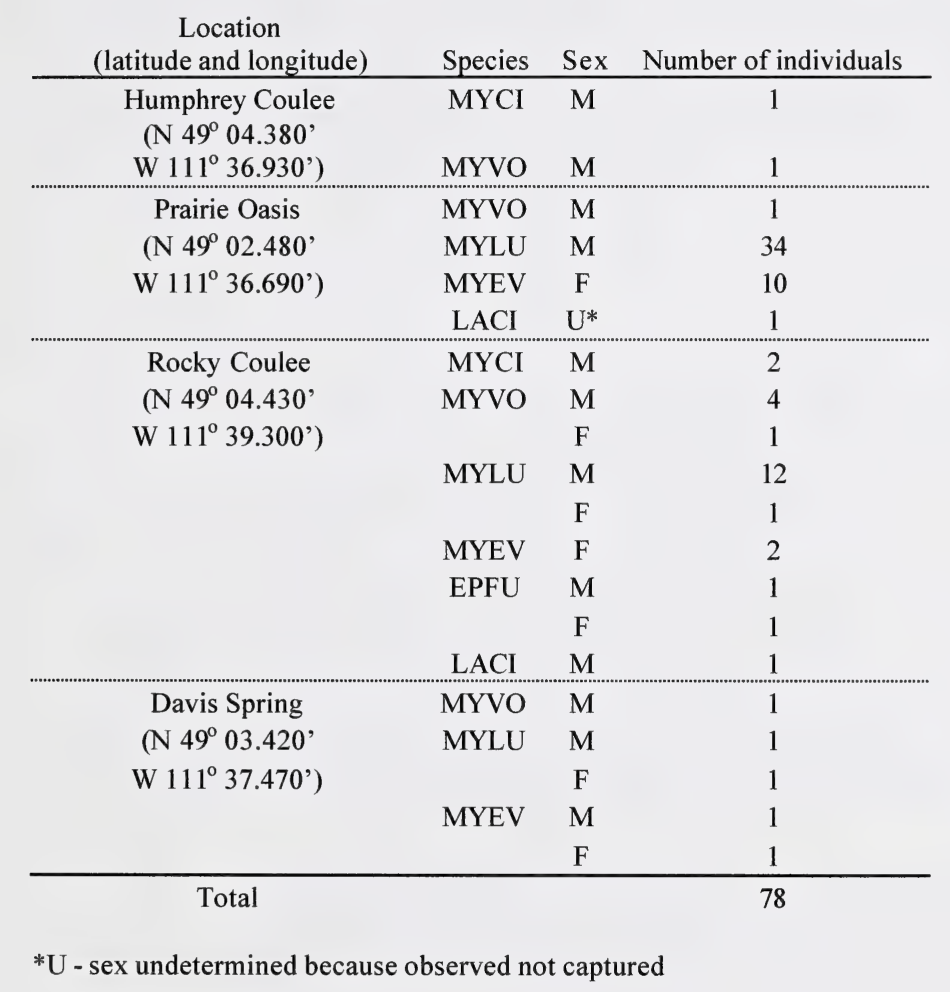





\section{Previous Extensive Captures}

M. Saunder's data for 1987 and 1988 are presented in Table 3. Netting took place in the public and reserved areas of the Park, on the north and south sides of the river, and on private lands bordering the park. Specifically, in the south area of the park he netted Police, Rocky and Davis Coulees. Seven species were captured, with $M$. lucifugus being most abundant $(350 / 575 ; 61 \%$ of captures). Adult sex ratio was also skewed for this species (206/312;66\% males). Based on these extensive netting records, species abundance is as follows, from most to least abundant in the WOS area: M. lucifugus, M. volans, $M$. ciliolabrum, and $M$. evotis.

\section{Compilation of Captures}

Since 1985, most netting of bats, excluding the work of M. Saunder's, took place at the WOS campground. These campground captures were poorly documented as most netting was done not for survey purposes, but for public presentation. R. M. R. Barclay had records of capture data from a southern Alberta park survey done on 26 July, 1985 (WOS, $n=8$ ). I netted the campground area for presentation purposes in 2001, 2002 and $2003(n=60)$. The latter two data sets, together with campground captures made by M. Saunders in 1987 and 1988, are compiled in Table 4. Additional campground capture data from R.M.R. Barclay could not be located. Similarly, capture records from S. Holroyd and L. Wilkinson were not located; L. Wilkinson netted the campground area one day each summer in 1991, 1992 and 1993 for presentation purposes and recalls capturing mostly M. lucifugus in addition to one Lasiurus cinereus (pers. comm.).

I combined captures made at the campground with captures made in the surrounding area (WOS park and neighboring private lands) from 1985-2003, for a total of seven species (Eptesicus fuscus, Myotis ciliolabrum, M. evotis, M. lucifugus, M. volans, Lasiurus cinereus, Lasionycteris noctivagans) and 722 captures or observations ( 575 captures by M. Saunders, 69 additional campground captures in conjunction with public presentations, 78 captures/observations this survey). 

Table 3. Bat captures made in 1987 and 1988 by Matt Saunders in WOS Park and surrounding area. Males (M) and females (F) are counted separately as are juveniles (Juv), and in some cases sex was not recorded (Undet.). The following species abbreviations are used: EPFU (Eptesicus fuscus), LACI (Lasiurus cinereus), MYCI (Myotis ciliolabrum), MYEV (Myotis evotis), MYLU (Myotis lucifugus), MYVO (Myotis volans) and LANO (Lasionycteris noctivagans).

\begin{tabular}{|c|c|c|c|}
\hline Species & Sex & $\begin{array}{l}\begin{array}{l}\text { Number } \\
\text { captured }\end{array} \\
\end{array}$ & $\begin{array}{c}\text { Total number } \\
\text { per species }\end{array}$ \\
\hline \multirow[t]{4}{*}{ EPFU } & $\mathrm{M}$ & 15 & 26 \\
\hline & F & 9 & \\
\hline & Juv M & 2 & \\
\hline & Juv F & 0 & \\
\hline \multirow[t]{4}{*}{ LACI } & M & 2 & 6 \\
\hline & F & 1 & \\
\hline & Juv M & 1 & \\
\hline & Juv F & 2 & \\
\hline \multirow[t]{4}{*}{ MYCI } & M & 16 & 40 \\
\hline & $\mathrm{F}$ & 23 & \\
\hline & Juv M & 0 & \\
\hline & Juv F & 1 & \\
\hline \multirow[t]{5}{*}{ MYEV } & $\mathrm{M}$ & 18 & 32 \\
\hline & $\mathrm{F}$ & 12 & \\
\hline & Juv M & 0 & \\
\hline & Juv F & 0 & \\
\hline & Undet & 2 & \\
\hline \multirow[t]{5}{*}{ MYLU } & M & 206 & 350 \\
\hline & F & 106 & \\
\hline & Juv M & 21 & \\
\hline & Juv F & 16 & \\
\hline & Undet & 1 & \\
\hline \multirow[t]{4}{*}{ MYVO } & M & 53 & 119 \\
\hline & F & 54 & \\
\hline & Juv M & 6 & \\
\hline & Juv F & 6 & \\
\hline \multirow[t]{3}{*}{ LANO } & F & 2 & 2 \\
\hline & Juv M & & \\
\hline & Juv F & & \\
\hline Total & & & 575 \\
\hline
\end{tabular}


Table 4. Summary of bat captures made in the public area/campground at WOS Park from 1985 to 2003, including M. Saunder's data. Males (M) and females (F) are counted separately as are juveniles (Juv). The following species abbreviations are used: EPFU (Eptesicus fuscus), LACI (Lasiurus cinereus), MYCI (Myotis ciliolabrum), MYEV (Myotis evotis), MYLU (Myotis lucifugus), MYVO (Myotis volans) and LANO (Lasionycteris noctivagans).

\begin{tabular}{|c|c|c|c|}
\hline Species & Sex & $\begin{array}{l}\text { Number } \\
\text { captured }\end{array}$ & $\begin{array}{l}\text { Total number } \\
\text { per species }\end{array}$ \\
\hline \multirow[t]{4}{*}{ EPFU } & $M$ & 6 & 6 \\
\hline & F & 0 & \\
\hline & Juv M & 0 & \\
\hline & Juv F & 0 & \\
\hline \multirow[t]{5}{*}{ LACI } & M & 2 & 3 \\
\hline & $\mathrm{F}$ & 0 & \\
\hline & Juv M & 0 & \\
\hline & Juv F & 0 & \\
\hline & Undet & 1 & \\
\hline \multirow[t]{4}{*}{ MYCI } & M & 4 & 13 \\
\hline & F & 9 & \\
\hline & Juv M & 0 & \\
\hline & Juv F & 0 & \\
\hline \multirow[t]{4}{*}{ MYEV } & M & 7 & 9 \\
\hline & F & 2 & \\
\hline & Juv M & 0 & \\
\hline & Juv F & 0 & \\
\hline \multirow[t]{4}{*}{ MYLU } & M & 88 & 172 \\
\hline & F & 56 & \\
\hline & Juv M & 14 & \\
\hline & Juv F & 14 & \\
\hline \multirow[t]{4}{*}{ MYVO } & M & 26 & 75 \\
\hline & F & 44 & \\
\hline & Juv M & 3 & \\
\hline & Juv F & 2 & \\
\hline \multirow[t]{3}{*}{ LANO } & $\mathrm{F}$ & 3 & 4 \\
\hline & Juv M & 1 & \\
\hline & Juv F & 0 & \\
\hline
\end{tabular}

Total

282 



\section{DISCUSSION}

\section{Species diversity}

Bats have been captured at Writing on Stone Provincial Park periodically since 1985. Over seven hundred bats have been captured in WOS Park and surrounding area. Both north and south portions of the park have been surveyed, although the majority of netting has taken place on the north side of the river due to its accessibility and proximity to the public areas. This report summarizes the majority of the bat captures. Seven species of bats have been captured in the park and the surrounding river valley area: Myotis lucifugus (most abundant in all capture records), M. volans, M. ciliolabrum, M. evotis, Eptesicus fuscus, Lasionycteris noctivagans, and Lasiurus cinereus. M. Saunder's capture data suggest that $M$. volans may be the second most prevalent species in the area. This species' status rank is currently 'undetermined' (Table 5) because of data deficiencies, therefore, the WOS area may be an excellent site to base an extensive radiotelemetry and roost characterization study for this species.

Table 5. The status of Alberta Chiroptera captured at Writing on Stone Provincial Park (Alberta Sustainable Resource Development 2000).

Common Name

Little Brown Myotis

Long-eared Myotis

Long-legged Myotis

Western Small-footed Myotis

Silver-haired Bat

Big Brown Bat

Hoary Bat
Scientific Name

Myotis lucifugus

Myotis evotis

Myotis volans

Myotis ciliolabrum

Lasionycteris noctivagans

Eptesicus fuscus

Lasiurus cinereus
Status Rank

Secure

Secure

Undetermined

Sensitive

Secure

Secure

Secure

Corynorhinus townsendii, or the Townsend's big-eared bat, is a species found in two of Alberta's neighboring provinces/states, British Columbia and Montana. I have captured males and reproductive females of this species on the Missouri River in Montana in prairie river badlands habitat similar to that of the Milk River, and there is a record of a C. townsendii capture (1874; Montana Fish and Game, K. Dubois, pers. comm.) on Waterton Lake, $<5 \mathrm{~km}$ from the Alberta border. It is therefore reasonable to assume that this species might be found in Alberta. I have netted bats extensively along the Milk River; in addition to WOS Park, I have netted at the Pinhorn Grazing Reserve (2002, 2003), $55 \mathrm{~km}$ downriver of the WOS, and at Havre, MT (2003), an additional $100 \mathrm{~km}$ downriver. I have never captured C. townsendii on the Milk River, despite similar prairie river valley habitat to the two sites on the Missouri River where I have captured C. townsendii: Coal Bank Landing, $70 \mathrm{~km}$ south of Havre, and McClelland Ferry Crossing, $80 \mathrm{~km}$ further downriver. All of the above-mentioned prairie river valley netting sites are alike in that they have cottonwood trees along the river and eroded sandstone valley walls (badlands). At all sites I caught Myotis 

lucifugus, M. ciliolabrum, M. evotis, M. volans (none at Havre), and E. fuscus. However, along the Missouri River, I also captured C. townsendii.

Why C. townsendii is not found along the Milk River, I can only speculate. The distribution of this species is known to be limited by the availability of roosts (Sherwin et al. 2003), which are deep caves and mines (Kunz and Martin 1982). Both caves and mines are present only where certain geological conditions exist; while it is difficult for me to comment on deep caves as these may go undetected in some areas, old underground coal mines exist at both Coal Bank Landing and McClelland Ferry (pers. obs. and S. Sanford, and E. Alderdice, local residents, pers. comm.). To the best of my knowledge, no abandoned underground mines exist around the WOS Park area, nor further downriver on the Milk River.

C. townsendii typically forage on a nightly basis two to eight kilometers from their roost (Dobkin et al. 1995), and I have netted them $(\mathrm{n}=24$; unpublished data) on the Missouri River throughout the entire night. As such, I believe that a sufficient netting effort has taken place at WOS Park (and several areas further downriver) to conclude that colonies of $C$. townsendii do not currently exist there. In Alberta, suitable badlands habitat does not exist upriver of the WOS Park area, and therefore it is unlikely that $C$. townsendii will be found on this stretch of the Milk River either. Likewise, because much of the Montana Milk River between the Canadian border and Havre is flooded by the Fresno Dam, because I have extensively netted the rocky riparian area between the Dam and Havre without capturing C. townsendii, and because suitable rocky riparian habitat on the Milk River ends at Havre, this species likely does not exist on the Milk River between the Canadian border and the confluence with the Missouri River.

While absence of deep caves and/or underground mines may explain the absence of $C$. townsendii from the Milk River in Alberta, the absence of continuous suitable rocky riparian habitat from the Rocky Mountains through to WOS Park may also restrict the distribution of this species. While my captures of $C$. townsendii represent the first record of this species on the Missouri River in Montana, a single $C$. townsendii was captured on the Marias River near its confluence with the Missouri (1959; Montana Fish and Game, K. Dubois, pers. comm.), suggesting that continuous suitable rocky riparian habitat may exist between the Rocky Mountains and the prairies of North Central Montana. Continuous habitat may be important for this species given that its seasonal movements between hibernaculum and maternity roost tend to be short (e.g. $<24 \mathrm{~km}$; Dobkin et al. 1995).

\section{Sex ratios}

Of interest is the adult sex ratio skew of M. lucifugus. Documented sex ratio skew for this species typically is female-biased due to the tendency for this species to form maternity colonies in summer months, especially in buildings (Schowalter et al. 1979). M. Saunder's data were less male-biased than mine. This may be the result of his data being collected over a much longer time period, or may reflect that his netting also included the public campground area (north side of river) where a maternity colony of $M$. lucifugus exists, whereas my netting surveyed coulees south of the river (Restricted Area) only. I have documented a similar situation on the Milk River at Havre, MT where almost all M. lucifugus captured 

outside of the city in the river valley were male $(19 / 21,90.5 \%$ male; $2 / 21,9.5 \%$ female, all nonreproductive; unpublished data), but netting near a known building maternity colony resulted in nearly all female captures $(58 / 69 ; 84 \%$ female, unpublished data). This may reflect differential thermo regulatory roosting requirements between the sexes (e.g. Vaughan and O'Shea 1976; Lausen 2001) in conjunction with foraging space.

\section{Habitat notes}

In prairie environments, water tends to be scarce, as are the cottonwood trees associated with sources water. Bats drink water from standing or slow-moving bodies of water, and forage among trees surrounding these bodies of water where insect concentrations tend to be high. Small prairie water bodies such as the "Prairie Oasis" netted in this survey can be very important to prairie bats (Holloway 1998). Bats were captured (M. evotis, M. lucifugus, M. volans) or observed (Lasiurus cinereus) around this spring throughout the entire night. Because this prairie site was quite remote (on flat land, $4.6 \mathrm{~km}$ from the river), I did not anticipate a large number of bat captures. Consequently, I placed nine nets around this small spring to be manned by three people. At emergence time, nets were immediately inundated with bats, and a large number escaped before they could be removed from the nets. Several nets were closed early in the evening to decrease captures to a manageable level. The popularity of this site suggests that this spring with its few associated trees is important habitat to bats in WOS Park, and efforts should be made to ensure its persistence. 



\section{CONCLUSIONS AND RECOMMENDATIONS}

I believe that all species of bats regularly roosting in the Writing on Stone Park area during the summer months have been identified. While the habitat seems suitable for Corynorhinus townsendii, and the relatively close proximity to other $C$. townsendii captures suggests that this species should be present along the Milk River, C. townsendii does not seem to exist along the Milk River in Alberta. This may be due to the lack of underground mines or suitable deep caves along the Milk River, or perhaps due to the lack of continuous suitable roosting habitat along the entire length of river. This report is a summary of the effort that has gone in to locating bat species in southern Alberta along the Milk River. While $C$. townsendii has not been located here, I believe that this bat may still be found in this province; similar extensive netting (and echolocation detection) effort should be carried out in the Waterton National Park (WNP) area of southwestern Alberta; given that deep caves may be found in the Rocky Mountains of this area, and that a $C$. townsendii was captured $<5 \mathrm{~km}$ south of WNP, I believe that this area holds promise of being part of the $C$. townsendii range.

I recommend that future bat research efforts in the Writing on Stone Provincial Park area focus on Myotis volans, because this species' status is undetermined and roosts and foraging behaviours have not been characterized for this species. M. volans appears to be present in sufficient numbers in the WOS area, making the study of this species feasible in this location.

\section{ACKNOWLEDGEMENTS}

Funding for this survey and capture summary was provided by Alberta Heritage Information Centre, Parks and Protected Areas Division. Previous capture records were made available by R.M.R. Barclay at the University of Calgary. I thank E. Baerwald for her volunteer work as my field assistant; T. Schowalter for planning this survey, arranging funding and assisting in the field; B. Ward and B. Moffet for logistical support while at Writing on Stone Provincial Park. 



\section{REFERENCES CITED}

Alberta Sustainable Resource Development. 2000. The general status of Alberta wild species 2000. Fish and Wildlife Service, Alberta Sustainable Resource Development, Publication No. 1/023. 46pp.

Dobkin, D.S., R.D. Gettinger and M.G. Gerdes. 1995. Springtime movements, roost use, and foraging activity of Townsend's Big-Eared bat (Plecotus townsendii) in Central Oregon. Great Basin Naturalist 55: 315-321.

Holloway, G. 1998. The ecology of prairie-dwelling bats in Southeastern Alberta. M. Sc. Thesis, University of Calgary; Calgary, Alberta.

Holroyd, S. L. 1993. Influences of some extrinsic and intrinsic factors on reproduction by big brown bats (Eptesicus fuscus) in southeastern Alberta. M. Sc. Thesis, University of Calgary; Calgary, Alberta.

Kunz, T.H. and R.A. Martin. 1982. Plecotus townsendii. Mammalian Species 175: 1-6.

Lausen, C.L. 2001. Thermoregulation and roost selection by reproductive big brown bats (Eptesicus fuscus) roosting in the South Saskatchewan River Valley, Alberta: rock-roosting and buildingroosting colonies. M. Sc. Thesis, University of Calgary; Calgary, Alberta.

Nagorsen, D.W. and R.M. Brigham. 1993. Bats of British Columbia. UBC Press, Vancouver.

Sherwin, R.E., D. Stricklan, and D.S. Rogers. 2000. Roosting affinities of Townsend's Big-Eared bat (Corynorhinus Townsendii) in Northern Utah. Journal of Mammalogy 81:939-947.

Schowalter, D.B., J.R. Gunson, and L.D. Harder. 1979. Life history characteristics of little brown bats (Myotis lucifugus) in Alberta. Canadian Field Naturalist 93: 243-251.

Vaughan, T. A., and T. O'Shea. 1976. Roosting ecology of the pallid bat, Antrozous pallidus. Journal of Mammalogy 57: 19-42. 

APPENDIX. The bat netting site at "Prairie Oasis", a site located at the upper end of Davis Coulee.

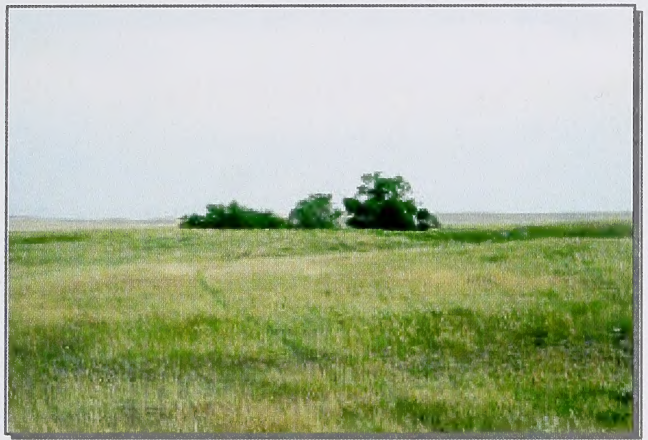

"Prairie Oasis' from a distance

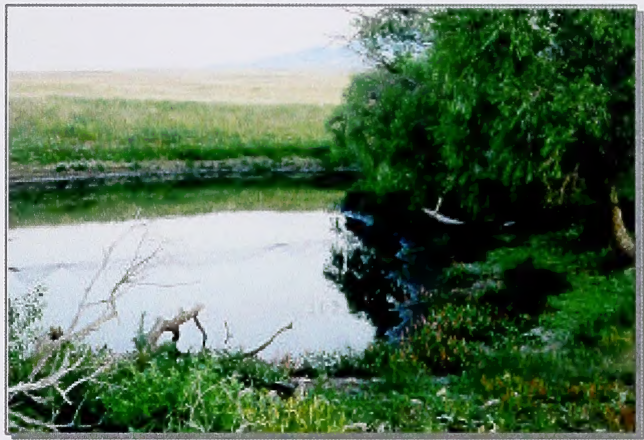

Note the folded mist net across the opening

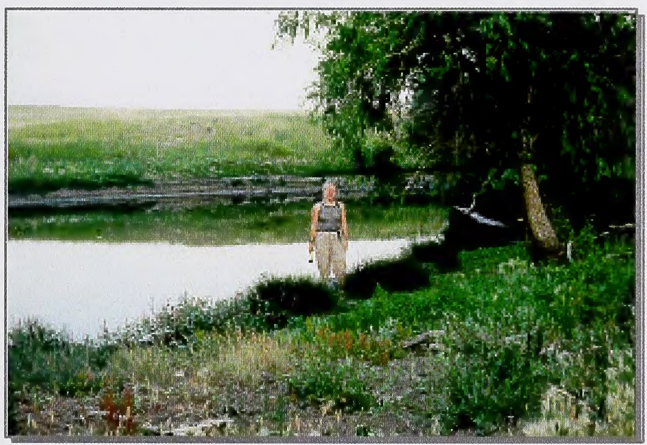

The author at 'Prairie Oasis'

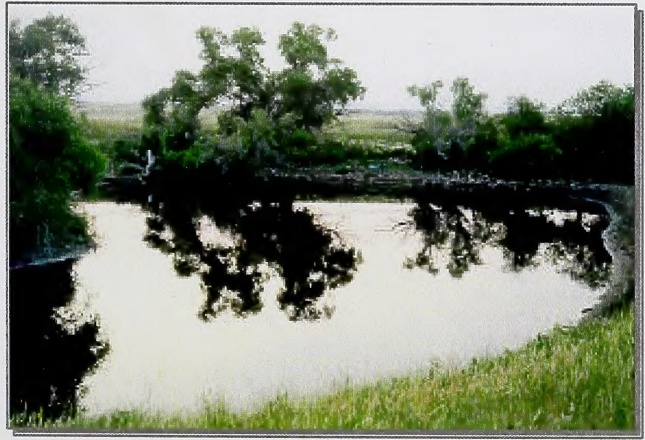

Mist nets were strung between tree openings

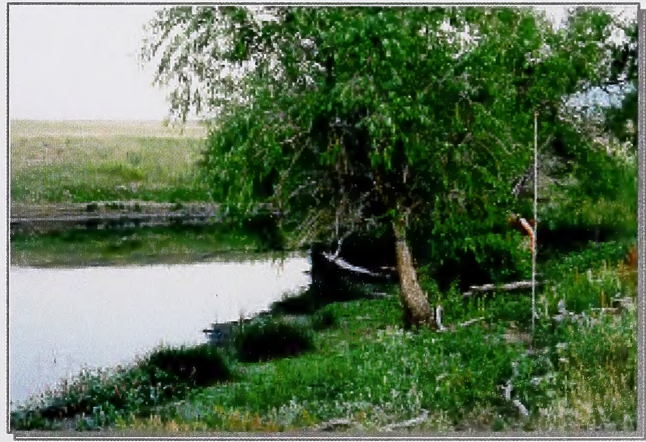

Folded mist net at 'Prairie Oasis' 
NATIONAL LIBRARY OF CANADA
Bibliothèque national

33286528544279 